\title{
ARTICLE
}

\section{Carrying capacity: the tradition and policy implications of limits}

\author{
Virginia Deane Abernethy* \\ Vanderbilt University School of Medicine, 209 Oxford House, Nashville, Tennessee 37232-4245, USA
}

\begin{abstract}
Within just the last few centuries, science and technology have enlarged human capabilities and population size until humans now take, for their own use, nearly half of the Earth's net terrestrial primary production. An ethical perspective suggests that potentials to alter, or further increase, humanity's use of global resources should be scrutinized through the lenses of self-interested foresightedness and respect for non-human life. Without overtly invoking ethics, studies of the carrying capacity achieve just this objective. Carrying capacity is an ecological concept that expresses the relationship between a population and the natural environment on which it depends for ongoing sustenance. Carrying capacity assumes limits on the number of individuals that can be supported at a given level of consumption without degrading the environment and, therefore, reducing future carrying capacity. That is, carrying capacity addresses long-term sustainability. Worldviews differ in the importance accorded to the carrying capacity concept. This paper addresses three world-views - ecological, romantic, and entrepreneurial - and explores the ethics and the policy implications of their contrasting perspectives.
\end{abstract}

KEY WORDS: Carrying capacity $\cdot$ Population $\cdot$ Environment $\cdot$ Limits $\cdot$ Ethics $\cdot$ World-views

\section{INTRODUCTION}

Environmental carrying capacity is a venerable, if hypothetical, ecological concept that has acquired fresh currency in light of the growing human population. It relates individuals to quantity of resources and quality of life, so it implies limits.

Familiar to stock-growers - year in and year out, for example, it takes 30 acres to support a cow-calf unit on typical Wyoming range-land - the concept of carrying capacity in the modern context refers to the number of humans who can be supported without degrading the natural, cultural and social environment. Exceeding the human carrying capacity implies impairing the environment's ability to sustain the desired quality of life over the long term. The appropriate comparison is to a too-dense cattle herd that finds sufficient feed for several years, but at the cost of over-grazing so that the

*E-mail: virginia.abernethy@mcmail.vanderbilt.edu land's future yield is reduced to below the original level.

The concept of carrying capacity is widely discounted, in part because it is fluid and virtually unquantifiable. Past discoveries and technological breakthroughs have, many times, raised carrying capacity, and much western science encourages the belief that technology's potential is unlimited. Technological optimists typically reject scientific warnings that no substitutes exist for topsoil, fresh water, clean air, and the "free services" of many species, or that technology and its deployment to replace existing uses of petrochemical energy will take 20 years to bring on line, minimum. The standard answer to evidence that a non-renewable resource is being depleted, or a renewable one degraded, is that, if a resource becomes "scarce" or pollution too detrimental, prices will rise sufficiently to call forth either substitutes or innovative technology that overcomes the problem. Technology and market mechanisms, it is said, will always enable humans to overcome putative natural limits. 
Economic cornucopians point to low (even falling) prices for essential commodities and staples, arguing that they give no sign of impending scarcity. Economic pricing theory is conveniently ignored, although this suggests that a purely competitive market - which describes many agricultural sectors - as opposed to a monopolistic market often induces producers to go on producing regardless of price signals. Pure competition may, indeed, promote increased production as a strategy for maintaining a constant income stream in the face of declining prices.

Oil production in the late 1990s, when a barrel of oil was priced at approximately $\$ 10.00$, exemplifies the price and production effects of relatively pure competition even when the resource in question is actually limited. Producer countries in the mid-East are dependent on oil revenues to maintain the various consumer subsidies to which their populations have become accustomed. In the face of low prices, production surged in order to maintain the needed revenue. Only when the Organization of Petroleum Exporting Countries (OPEC) re-exerted production caps did prices rise. The leaders and the citizenry of industrialized countries seldom interpret the higher price of oil or natural gas as a sign of scarcity. Many remain convinced that prices are arbitrarily manipulated. The production quotas set by oil producing countries are not seen as sensible responses that have much to do with knowledge about the limited quantity of the underlying resource.

Mixed evidence often leads to rejecting the concept of carrying capacity, possibly because it is reassuring inherently more pleasing - to believe that humanity has escaped from limits that constrain the growth of all other species. Moreover, much in western history warrants such confidence. For example, in the last decades of the nineteenth century, just as the United States' eastern forests were about depleted, crude oil was discovered and put to multiple uses formerly met by wood fuel.

Ecologists, partisans in the ongoing debate, not only assert that limits to essential resources and the threat of both local and global pollution are apparent already, but also warn of a threshold effect. They point out that a boundary condition can be encountered suddenly. Simplistically, a person jumping off a forty-story building might enjoy the ride until brought up short by the landing. A standard requiring total certainty - such as the landing - carries a risk. This risk is that proof of the carrying capacity's being exceeded may come only after much damage - and perhaps irretrievable damage - has been done.

If optimistic forecasts are wrong and a natural threshold is crossed, the consequence could be calamitous. Nevertheless, proof sufficient to convince skep- tics remains elusive. Many experts and opinion-makers contend that most difficulties are temporary, requiring only the right fix. The inexactness of carrying capacity models encourages that perspective. An exact limit for a local population is rarely if ever established.

Yet, population studies in human and other animal populations repeatedly show that exceeding this uncertain limit, the carrying capacity, results in catastrophic change. When do problems start to be seen as intractable? When does the perceived cost of being wrong about unlimited technological potential outweigh the perceived cost of being wrong about limits where none, in fact, exist?

\section{Realms of disagreement}

Disagreement about the theoretical validity of conceptualizing and estimating ecological limits, and its practical ramifications, is only the beginning. Attitudes toward limits can be expressed in different realms, becoming virtually an existential issue. One major philosophical tradition denies limits to humanity's moral capacity. The divergence in schools of thought reaches into policy.

In mid-eighteenth century France, controversy over limits hinged on human moral capabilities. FrancoisMarie Arouet de Voltaire dramatized the conflict of worldviews in Candide. Early in the plot, a trusting Pangloss confidently reassures Candide that they are living in the best of all possible worlds. Ultimately, a world-worn and soberer duo settle for improving their own backyard, "Cultiver son propre jardin."

Opposed to Voltaire's eighteenth century rationalist view were the romanticists Jean Jacques Rousseau and Condorcet in France and William Godwin, father of Mary Shelley, in England. Central to their belief was the imagining - untroubled by modern archeology - of the uncorrupted "noble savage" of the Americas, which ostensibly proved to their satisfaction the (re)perfectibility of man and of society in the context of living harmoniously with nature.

\section{Historical notes}

The eighteenth and nineteenth century controversy about physical limitations was concerned less with absolutes than with the balance between population and resources. A maelstrom swirled around Thomas Robert Malthus, whose famous first edition of his essay on population was published on June 7, 1798. Malthus argued that most humans would reproduce up to, or even surpass, the limit of resources available to them. 
The Malthusian observation invites the conclusion that most people find sustained prosperity elusive, because technological progress or other addition to wealth stimulates population growth. This growth eventually restores the original ratio of resources to people.

Malthus is remembered for the elegance and force of his argument; however, the essential element of his thought had been anticipated. Writes ecologist Garrett Hardin, "Two thousand years ago Koheleth, the Preacher, said in Ecclesiastes 5:11: 'When goods increase those who eat them increase.' "Similarly, "the English philosopher David Hume, in 1752, played a variation on the theme in Ecclesiastes: 'Where there is room for more people, they will always arise'" (Hardin 1998a). Malthus, a theologian and political scientist, surely knew both sources.

\section{THREE WORLD VIEWS}

The conflicting worldviews on limits to both resources and human moral capacities descend to the present. The taxonomy proposed here identifies three patterns and is admittedly an oversimplification. But a division into ecological, entrepreneurial, and romanticist traditions - loose classification though it is - may partially illuminate present-day political and issue coalitions that might otherwise seem mystifying.

\section{Entrepreneurs}

The entrepreneurial tradition relies on individual initiative and contractual relationships for the betterment of mankind and society, and is mainly skeptical of the moral perfectibility of human kind. In the tradition of John Locke, it assumes that pursuit of private ends can serve the common good because the incentive to increase personal property often results increasing the total wealth that a society may ultimately enjoy. Proponents are pragmatists and, often, self-styled conservatives.

The dominant motive acknowledged in oneself and generally attributed to others is not altruism but selfinterest, - as in the Declaration of Independence' guarantee of the "pursuit of happiness" - which is taken to be a virtually universal human characteristic that can be socially channeled to become usually positive in effect. Competitive self-interest reinforced by good information and accountability is expected to yield a well-regulated society, rational markets, prosperity founded on market principles, and fair government. The entrepreneur advocates free trade and ample immigration so long as these policies appear to enhance net profits. They rely not on perfecting human moral instincts but, rather, on the social contract for mutually-agreed governance.

The entrepreneur's differential views of limits depending upon their reference to moral or physical realms suggest a pragmatic rather than ideological foundation. Pragmatists are swayed by evidence.

Technological innovations that quadrupled carrying capacity since the Malthusian era are the basis for the entrepreneur's skepticism that material limits are real and close. A 1997 essay in The (London) Economist points out that "predictions of ecological doom, including recent ones, have such a terrible track record that people should take them with a grain of salt." The essay continues, "...journalists and fame-seekers will no doubt continue to peddle ecological catastrophes at an undiminishing speed. These people, oddly, appear to think that having been invariably wrong in the past makes them more likely to be right in the future" (Environmental Scares, 1997, p.19).

Reasonably enough, this essay appeals to the historical record. Why would the future be different?

As the twentieth century closes, many entrepreneurs accept the assumptions relating to technology and the physical world that have been provided, in large measure, by Julian Simon. This is the late University of Maryland economist, author, and editor of the rose-colored-wrapper compendium The State of Humanity (1996) and pro-immigration tracts such as Immigration: The Demographic and Economic Facts (1995).

Simon's premise is that limits to natural resources as well as the environment's capacity to cope with pollution invariably yield to the transformations made on nature by technology. Thus, natural constraints are merely challenges, ultimately irrelevant to the economy. Technology will refresh or give us substitutes for clean air and water, rich topsoil, cheap fossil fuels, and Earth's services in detoxifying pollution. That is, manmade capital can substitute for natural resources indefinitely and without end; repeated doublings of the size of the economy and population present only opportunity. Whatever accelerates growth should be pursued.

In 1995, a Washington, D.C. think-tank, the Cato Institute, published Simon's nigh-incredible cornucopian assertion that "Technology exists now to produce virtually inexhaustible quantities of just about all the products made by nature." Extending his foray into the world of science, Simon writes, "We have in our hands now -- actually in our libraries -- the technology to feed, clothe and supply energy to an evergrowing population for the next 7 billion years... Even if no new knowledge were ever gained... we would be able to go on increasing our population forever..." (Cato Institute 1995, p. 14). 
Note that 7 billion years ago was about two and a half billion years before the first one-celled life form appeared in Earth's newly formed primal ooze. Can one have confidence in the author of prognostications for 7 billion years into the future?

Physicist Albert A. Bartlett of the University of Colorado is a gentleman inclined to give adversaries the benefit of the doubt. Therefore, he was pleased to report that Simon did not entirely mean what he wrote: "Simon said that the '7 billion years' was an error and it should have been ' 7 million years.'" But, Bartlett continues, "It is too early to breathe easily." Given the 1996 world population of approximately 5.7 billion and an annual population growth rate of 1 percent, world population after 7 million years would be equal to $2.3 \mathrm{x}$ 1030410. "This is a fairly large number!" (Bartlett 1996).

Non-mathematicians might like to know that $2.3 \mathrm{x}$ 1012 is 2.3 trillion (American definition of "trillion"). So how large is a number with the exponent of not 12 but 30410 ?

The hard-line cornucopian view also has champions in Dennis T. Avery of the Hudson Institute and author of Saving the World with Pesticides and Plastic (1995), and Thomas Lambert of the Center for the Study of American Business (CSAB). Lambert writes that, "natural resources are not limited in any meaningful sense" because resources are really best understood as services. It is, after all, "the particular services a material provides -- not its physical composition -- that makes a material a resource" (Lambert, 1996, p. 5).

While appealing in their reasonableness (unlike Simon), Lambert's and Avery's visions deny the implications of the environment's being an envelope around the economy. Yet, the environment provides inputs to economic production, and the environment receives not only the useful but also the waste products of economic activity. As put by economist Herman Daly, "The economy is a wholly-owned subsidiary of the environment."

The ecology response to the cornucopian vision

Ecologists and certain economists - for example, Daly (1990; 1991; Cobb and Daly, 1990) - point out that technology can employ (or alter or discover) one resource to make up for shortfalls in another, and use assorted strategies to minimize pollution, but these expedients only change the pressure point. One cannot avoid the risk of shortfalls or bottlenecks developing in the substitutes and during the transformation process. Difficulty is compounded if the real world has a propensity to develop problems in multiples, not one at a time. In times of stress, anything that can go wrong, might go wrong. How does technology cope with the snowball effect? "With difficulty," answers an ecologist or old-fashioned conservative. And, "Why take the risk?"

\section{The energy constraint}

Since mid-century (Cottrell, 1955), growing numbers of scientists have tried to make the public aware that the large increase in carrying capacity has been possible only because of readily available fossil fuels, especially oil. Walter Youngquist (1997), Colin Campbell, L.F. Ivanhoe, Richard Duncan and others suggest that a peak in oil production in the vicinity of 2005 to 2015 A.D. will be followed by steady decline. Natural gas is expected to be plentiful for about 40 years after the peak in oil production, and new processes are likely to increase its versatility. Without fossil fuels, it would probably be impossible to farm the vast acreage that has made possible the present population size.

In November, 2000, geologist Richard Duncan addressed a Geological Society of America "summit" held in Reno, Nevada. Citing historical data, Duncan shows that world energy production per capita grew by 3.45 percent annually between 1945 and 1973; growth slowed to 0.64 percent annually from 1973 to 1979 ; then growth ended and began to decline at the rate of 0.33 annually from 1979 to 1999. Fitting a mathematical equation to data points on this curve, Duncan derives projections which suggest that, by 2030, energy production per capita will fall back to its 1930 value. This scenario envisions rolling, then permanent, blackouts of high-voltage electric power networks, worldwide.

\section{Industry}

Industry geologists are sanguine regarding the quantity and substitution possibilities for natural gas and other energy sources and do not yet state publicly that a peak in oil production is imminent. Nevertheless, more pessimistic forecasts are gaining ground (Banks 1998), and the Paris-based International Energy Agency (IEA) of the Organization for Economic Cooperation and Development (OECD) stated in 1998, for the first time, that "the peak of world oil production is in sight" (Kerr 1998). Were the majority to adopt the views of Campbell and others, entrepreneurial assumptions about limits might be readily reversed.

The habit of inductive reasoning makes entrepreneurs open to new perspectives. Sustained sharp price increases for essential commodities, rising public costs (higher taxes) associated with a rapidly growing population, and fees for the formerly-free services of nature 
would be persuasive to those of the entrepreneurial bent. Many who reject ecological statistics would be weaned from the conviction that wealth is both abundant and renewable by market and financial signals.

\section{Romanticists}

Contrasting with the pragmatism of the entrepreneurial sector, the romanticist tradition appears to be driven by ideology. Denying limits in all realms, romanticists assert an unlimited human moral capacity to do right. While conceding that some people go wrong, romanticists explain that humans are not expected to reach their full moral potential under impoverished or mean social conditions.

The development of true altruism - not mere reciprocal altruism - is the highest moral trait in the romantic pantheon, but it requires nurturing love and a sufficiency of goods. Thus, the theoretical perfectibility of humanity and human society carries a caveat regarding requirements for a supportive social and economic milieu. These presumptions are the source of advocacy for social reform and government regulation aimed at redistributing wealth in order to overcome deprivation.

Given that it is society's obligation to rehabilitate the less fortunate so that every potential for human perfectibility is actualized, it becomes axiomatic, for romanticists, that society can do it. The means exist. Romanticists trust that nature can provide without limit because, if the goal that all humans should have access to sufficient resources is to be realized, that is clearly necessary.

In the romanticist formulation, therefore, the ecologists' concept of carrying capacity is irrelevant, if not malevolent, because it sets an upper limit to the resources that ever can become available to humanity. Lest moral potentials not be fulfilled, social reformers are constrained to believe in boundless wealth that need only be equitably distributed in order to create the perfect society.

Independently, Garret Hardin has arrived at a similar analysis of the romanticist worldview. He cites in evidence Karl Marx's unprovoked ad hominem attacks on Malthus (in the vein of "'superficial,' 'a professional plagiarist'"). Hardin suggests that "a single overarching view accounts for these and many other invectives put forward by Marxists and liberals during the past century and a half: this is their tightly held denial of limits in the supply of terrestrial resources. Friedrich Engels, Marx's collaborator and financial supporter, asserted baldly that 'The productivity of the land can be infinitely increased by the application of capital, labour (sic), and science'" (Hardin 1998b, p.182).
The romanticist tradition is manifest in modern times among those who strive to advance internationalist and collectivist agendas. They believe in breaking down national boundaries because nation-states perpetuate disparities in wealth. University of Chicago professor Martha Nussbaum exemplifies the tradition in her teaching that "the concept of national citizenship is too exclusive and 'morally dangerous.' Justice and equality, she claims, require 'allegiance to the worldwide community of human beings' " (Erasing Self-Rule 1998, p.16). Romanticists support behavior and international institutions that tend to erode sovereignty.

Some who appear to favor world government try to deflect objections by asserting its inevitability. Joe De Courcy observes that, "On 17 February 1930, for instance, a leading member of the Council on Foreign Relations, James P. Warburg, told a U.S. Senate Committee: 'We shall have world government whether we like it or not...by consent or by conquest.' In 1976, Professor Saul Mendlovitz, director of the World Order Models Project, said there is ' ...no longer a question of whether or not there will be a world government by the year 2000.'" The stealth strategy is preferred by former Senator Alan Cranston (D-California), past president of United World Federalists. He "told Transition, a publication of the Institute for World Order, that: 'The more talk about world government, the less chance of achieving it, because it frightens people who would accept the concept of world laws' " (de Courcy 1998, pp. 34-35).

\section{Ecologists}

The ecological tradition is in almost all respects the opposite of the romantic-internationalist. Ecologists are strongly influenced by biology and many emerge from this academic discipline. Their views are formed from observation of natural systems, including behavior; that is, their method of reasoning is inductive, like the entrepreneur, although the two traditions attend to different data sets.

\section{Physical limits}

Ecologists accept the concept of carrying capacity as essentially self-evident. The Earth is round and finite; so, therefore, must be its resources and its capacity to cope with pollution (Bartlett, 1996; Pimentel and Pimentel 1991; 1996). Further, they see the imminence of carrying capacity limits in the deterioration of countless natural systems. Signs include the 15 out of 17 world fisheries that have crashed; falling water tables in aquifers; topsoil loss; annual oil production greater 
than discoveries (therefore, declining real reserves); mass extinction of species; and compromised capacity to cope with atmospheric and water pollution (Pimentel and Pimentel 1996; 1997).

Carrying capacity has greatest relevance to policy when viewed in local terms, because it often is not possible to affect the destiny of units larger than the local community or, at the outside limit, the nation. Information about the environment, including resources and vulnerabilities, is often best at regional or smaller levels. Further, cooperation is more easily mobilized at the neighborhood, state, or at least national level because it often depends upon kinship or friendship a sense of identity and shared interests that facilitates the exchange of favors over periods sometimes longer than a generation. In addition, the presence of a competitor is an incentive to cooperate. Communities that are vying with an opponent will be more likely to cooperate internally, but this motive cannot coexist with the ethos that all belong to one world.

Finally, ecologists apply the lesson of the "tragedy of the commons." In 1968 Garrett Hardin illuminated the essential characteristic of a commons, defining it as a resource from which no one can be excluded. Everyone has access to a commons.

The fact of universal access has major implications for the motivation to conserve because conservation depends upon self-restraint, saving a resource in order to enjoy or use it in the future. No one has the incentive to conserve a resource to which no one can be denied access, for the reason that those making the effort, or their descendants, are very unlikely to have much of the future benefit from their present sacrifices.

In a commons, in fact, the better individual strategy is to use the resource as intensively and fast as one can. The maxim is, "Use it or lose it," with a vengeance.

Organizations with the appearance of a commons have successfully conserved or even improved a resource, at times. But delving deeper into instances of this type invariably reveals a mechanism for excluding users. This holds true whether the resource is a forest, a fishing ground, or a village green for pasturing sheep. Informal mechanisms for regulating use can be effective, if often rough on transgressors, and the gradient of penalty may escalate. But regulation that lacks enforceable and meaningful sanctions is unlikely to protect a resource (Leal 1998; Ruttan 1998).

Thus, the moral hazard of the commons is the ultimate, logical reason why one-world, a world without borders, will not get one very far into a peaceful and prosperous future. If no person, and no community or country, can say, "Keep out; it's mine," then no one and no region or country has the incentive to conserve. And that, simply, is because there is almost no realistic hope of future benefit in proportion to one's effort and self-restraint.
Moral Limits

Ecologists tend to conclude that the physical capabilities of Earth and the moral capabilities of mankind are equally constrained by natural law. Humans are not so unlike other species that the principles of evolutionary biology would not apply to human behavior (Trivers 1971; Dawkins 1976; Wilson 1975). Survival and reproduction of one's genes is the de facto evolutionary test of success. Inevitably, behavior is shaped to increase the probability of survival.

By extension, moral codes are subject to the possibilities inherent in a physically-limited Earth. Ecologists take into account that humans are not generally altruistic, because altruism like other behavioral traits is to some extent heritable, and altruists are less likely than others to leave offspring (Hamilton 1964; Trivers 1971; Wilson 1975). Behavior and culture that lead to extinction of those who practice them cannot be moral, by definition. For example, if wastefulness in use of resources leads to extinction, then it cannot be moral. Nor can altruism including the sharing of resources, if it leads to extinction, be moral (Elliott 1997).

Altruism is particularly self-destructive when applied internationally. Those who advocate altruism must necessarily believe that nature is a cornucopia of unlimited means.

Accepting limits in principle and in fact, ecologists advocate not only prudence in use of resources but also discovery of motives which induce intrinsically self-interested humans to conserve. Thus, the moral hazard of the commons is the ultimate, logical reason why one-world, a world without borders, will not get one very far into a peaceful and prosperous future.

If no person, and no region or country, can say, "Keep out; it's mine," then no one and no community or country has the incentive to conserve. And that, simply, is because there is almost no realistic hope of future benefit in proportion to one's effort and selfrestraint.

To sum up the ecologist perspective, given the probability of coming scarcity, a multiplicity of logistic problems in increasing efficiency, and the realities of human nature - including political and ethnic loyalties - many ecologists suspect that the only practicable solutions to most environmental problems will be local.

\section{A COLLISION OF WORLDVIEWS}

The romanticist assumption that humankind and society are potentially perfectible, needing for fulfillment only that the planet's abundant resources should be equitably distributed, entails a surprising array of corollary axioms. The heirs of Rousseau and Marx 
advocate a world without borders, one-world. They reject the competitive efforts of one country or region to thrive beyond the realistic aspirations of any other. They espouse submerging national interests.

Applied to the United States, the one-world ideology is expressed in advocacy for reducing consumption to the average of world levels (substantially lower than present European levels of consumption) and for open borders. Part of the rationale for the latter goal is that the United States is unlike any other nation. It is a nation of immigrants having no history of a citizenry who feel united as a people, and therefore it has no legitimate territorial integrity. In short, the United States is not a nation-state like other countries of the world but is, rather, "an idea," appropriately stripped of sovereignty.

In the cultural and social realms, this description of America justifies accelerated immigration of peoples as unlike to existing Americans as possible, and advocacy of multiculturalism. Already a feature of public school (embodied in new, government-sponsored history standards) and many private school curricula, multiculturalism teaches that all cultures are equally relevant to America. Remarkably (and illogically within the terms of multiculturalism's own worldview) one culture is presented as illegitimate - destined to be overcome by others. That is the culture of the Founders based on European and particularly Anglo-Saxon principles of ethics, government, religion, and Euro-American history.

Others think differently on each of these dimensions. Whether it be the legitimacy of the nation, the sense of patriotism and kinship in being American, the inviolability of carrying capacity if the nation is to survive, or the means of protecting carrying capacity, ecologists begin from different premises and arrive at vastly different conclusions.

In addition, ecologists and entrepreneurs are converging on the view that humans are not altruists - the opposite of the romanticist credo. A factual basis for rejecting the myth of the "noble savage" is well developed. The current view is that altruism manifested in a conservation ethic is no more present in traditional than modern society (Williams 1966; Ruttan 1998).

Inductive reasoning is common to both ecologists and entrepreneurs but, focusing on different data, they arrive at different conclusions. At present, entrepreneurs assert that the greatest good derives from free trade and minimal impediments to the movement of labor. Attentive to natural systems, ecologists reach a conclusion - one also having policy implications - that is based on the limits of nature in general, and of human nature in particular.

It seems likely that the majority of ecologists and entrepreneurs (with the exception of multinational cor- porations) assume that the United States is a nationstate, like others, with territorial integrity and its own culture. Culture is taken to mean the values and assumptions, history, language, and technology that are largely shared by all members of the society. The government has its primary responsibility to the nation, the United States, and a corollary obligation to protect the nation's people, all Americans. It would not put the matter too strongly to assert that the government of the United States is obliged to put the wellbeing of Americans above all others, just as the governments of all other countries are expected to do for their people.

Preservation of carrying capacity, which is inherently limited, is fundamental for the present and future wellbeing of any nation. Over-taxing the carrying capacity destroys, sometimes irremediably, the longterm ability of the resource base to sustain those who depend on it.

Population growth indubitably increases the pressure on the environment - even romanticists admit this so long as their focus is the rest of the world rather than the United States (see, for example, the former VicePresident Albert Gore's Earth in the Balance [1992]). Concern about U.S. population growth pushes ecologists to protest present U.S. immigration policy which allows the addition of over1 million persons annually (net of emigration), as well as the subsequent growth from descendants of current immigrants. Immigration and the children of post-1970 immigrant families, together, accounted for over 70 percent of U.S. population growth in the decade of the 1990s (Camarota 1999). That share rises continuously as the stock of recent immigrants and their descendents grows and the native-born fertility rate remains low.

Ecologists see not only the direct threat to carrying capacity from increasing population size through immigration, but also the indirect effect arising from immigration's effect on the incentive system. Americans are disposed to conserve land that they own or control, to stabilize population through self-restraint in childbearing (the native-born fertility rate is below replacement level), to tax themselves for environmental rehabilitation efforts, and to mitigate ongoing environmental destruction. However, immigration makes the United States into an effective "commons," a condition conducive to using resources as fast as possible lest one lose out on one's share.

A rational person who sees no prospect of stabilizing population so long as immigration continues might well resist any sacrifice made on behalf of the environment or society at large (Abernethy, 1993). If efforts to protect the carrying capacity are doomed to fail, anyway, because of continuing population growth, why conserve, why do without today, why support an envi- 
ronmental ethic? A case in point, to protest continuing immigration, some Californians responded to wateruse restrictions during the 1980s drought with the bumper sticker, "Flush Twice."

Unless reasonably assured that present and future benefit will accrue to themselves or their posterity, few persons will forego present consumption or childbearing for the purpose of conserving the environment. This means that Americans' incentive to conserve the environment can probably be maintained only by offering hope that their efforts will not be in vain. Ecologists conclude that reducing immigration to the number compatible with stabilizing population size, or even allowing population decline should that prove necessary, is the only sustainable course.

\section{A POLICY COLLISION}

Translating worldviews into policy initiatives, partisans of the three distinct traditions find themselves joined in surprising coalitions. When the focus is on protecting a particular resource (a forest, a river, public lands), romanticists work together with ecologists. Romanticists and entrepreneurs (who desire access to the cheaper world labor market without moving production operations abroad) readily work together to defeat legislation that would reduce immigration numbers to a level compatible with U.S. population stabilization.

An instance of the serendipitous romanticist-entrepreneurial coalition was their mobilization to block a proposed reduction in numbers of legal immigrants in spring, 1996. The pro-immigration National Immigration Forum headed by Frank Sharry and the liberal Urban League as well as the National Association of Manufacturers and the National Trial Lawyers Association argued in concert - and successfully - for continuing high levels of legal immigration (Davidson 1995, p. 34; Chavez 1996; Levine 1996; Jacobs 1995; Freedburg 1996; Tech Firms 1996). However, this coalition fragments on conservation issues.

Divisions can be found within the entrepreneurial community itself. For example, Fred Charles Iklé, himself a conservative, takes neo-conservatives to task for their idealization of non-stop economic and population growth: "The fabulous success of conservative economic policies has seduced many in our midst into taking economic growth as the defining attribute of conservatism. These brethren now believe that...good growth can and must continue indefinitely. They act as if conservative thought were nothing but the philosophy of perpetual growth" (Iklé 1994, p. 36).

Warning against immigration-driven growth, conservatives might cite Lester Thurow, former Dean of
MIT's Sloane School of Business Administration, who postulates that "No country can become rich without a century of good economic performance and a century of very slow population growth" (cited in Lind 1995). In other contexts, Paul Krugman (1994) observes that "Economic growth that is based on expansion of inputs, rather than on growth in output per unit of input, is inevitably subject to diminishing returns." Robert Stein in Investors Business Daily, states that immigration dilutes the amount of capital available per job and thus undercuts the mechanism for raising labor productivity and non-inflationary wage increases (Stein 1995).

Ecologists attempt to appeal to the business community by pointing out that population growth makes more environmental regulation necessary and adds dramatically to the fiscal burden of local and state government. The more general arguments, that population growth threatens the carrying capacity, and immigration depresses the wages of American labor (very often the least skilled, already disadvantaged, are hurt most) seem more attuned to classical liberal thinking.

The competing rationales and outcomes appear reasonable or not depending upon one's perspective. Entrepreneurs hear restrictions on immigration as interference with free markets and the economies of low-wage labor - although an imported labor force displaces Americans who may then go on the public dole. Moreover, low-skill immigrants and their families are very likely to depend on public assistance (especially during months of slack employment), lack health care insurance, and have children who are educated at public expense (Matloff 1998; Huddle 1998). Calls for government programs to correct poverty are an almost inevitable result of importing poverty.

The radical-left element of the romanticist school hears immigration restriction as racist (Political Ecology Group 1998). Racism is inferred because reduced immigration would inevitably cut most from the largest streams of immigrants, which are from the third world and the former USSR. Further, one-world romanticists cast the attempt to conserve a unique American culture as illegitimate - although all nations, as a matter of course, intend to conserve their own language, history, traditions, and values. The charge of "racism" has successfully intimidated large numbers of Americans whose goals are conservationist and certainly not racist. I observe that the term, "Nazism," is being substituted as "racism" loses credibility and punch.

Conservationists place a high priority on the quality of life in their communities, and their goals encompass preserving good opportunity for coming generations of Americans. Most Americans look to the future. In the present, wishing to protect American workers from having their wages competed down to third world 
standards, citizens seek a healthful, open environment and minimization of government intrusion into their lives. The majority sees no need to reject the traditional culture, which is not only their birthright but also the safeguard of democratic government and Constitutionally guaranteed freedoms.

Every country has its interests and its culture. The culture evolves from within as most citizens wish it to do. Such has been the course of history. In a healthful state, the culture promotes a rate of growth, or stasis, where the natural environment sustainably supports the associated society at a level that is expected and acceptable to its citizens.

But romanticists deny the importance of both limits and western culture and, for the sake of a one-world, internationalist chimera in which everyone is equal, would see everyone poor. This cannot be right. The moral high ground must have a basis in environmental and human possibilities. Disrespect for the carrying capacity is destabilizing. It exacts, ultimately, a devastating toll.

\section{LITERATURE CITED}

Abernethy, V. (1993). Population Politics: The Choices that Shape Our Future. Plenum Press, NY.

Avery, Dennis T. (1995). Saving the Planet With Pesticides and Plastic. Hudson Institute, Indianapolis.

Banks, Howard (1998). Cheap Oil: Enjoy It While It Lasts. Forbes, June 15, pp. 84-86.

Bartlett, Albert A. (1996). The Exponential Function, XI: The New Flat Earth Society. The Physics Teacher, September, 34, 1-2.

Borjas, George (1996). The New Economics of Immigration. The Atlantic Monthly, November, pp. 72-80.

Borjas, G and Freeman R. (1997). Findings We Never Found. The New York Times, December 10, Op-Ed.

Chavez, Linda (1996). USA Today, p.1.

Camarota, Steven A. (1999). Immigrants in the United States - 1998. Center for Immigration Studies, Washington, D.C.

Cobb, J.B. Jr. and Daly, H.E. (1990). Free Trade versus Community: Social and Environmental Consequence of Free Trade in a World With Capital Mobility and Overpopulated Regions. Population and Environment, 11(3), 175192.

Cottrell, Fred (1955). Energy and Society. McGraw-Hill, New York.

Daly, Herman (1990). Toward some operational principles of sustainable development. Ecological Economics, 2, 1-6.

Daly, H. (1991). Population and Economics: A Bioeconomic Analysis. Population and Environment 12(3), 257-258,

Dawkins, R. (1976). The Selfish Gene. Oxford University Press, Oxford.

Davidson, J. (1995). Wall Street Journal, June 9, p. 34.

De Courcy, Joe (1997). Globalists v. the Nation State. The St. Croix Review, 31(2), 34-38.

Elliott, Herschel (1997). A General Statement of the Tragedy of the Commons. Population and Environment, 18(6), 515531.

Environmental Scares (1997). The Economist December 20, pp.19, 20.
Erasing Self-Rule (1998). Middle American News, June, p.16. Ferguson, Andrew (1998). "World Carrying Capacities." Optimum Population Trust, Manchester, England.

Freedburg (1996). Few Visas. San Francisco Chronicle, March 11, p. 1.

Gore, A. (1992). Earth in the Balance: Ecology and the Human Spirit. Houghton Mifflin, Boston.

Hamilton, W.D. (1964). The Genetical Evolution of Social Behavior. Journal of Theoretical Biology 7, 1-16.

Hardin, Garrett (1998a). The Number of Cars will Increase to Fill Six Lanes. January 18, p.G-4.

Hardin, Garrett (1998b). The Feast of Malthus. Social Contract $8(3), 181-187$.

Hardin, Garrett (1968). The Tragedy of the Commons. Science 162, 1243-1248.

Huddle, Donald (1998). Executive Summary, Immigration's Costs Keep Rising. Carrying Capacity Network, Washington, D.C.

Jacobs, Margaret A. (1995). U.S. Businesses Fight a Cutback of Green Cards. Wall Street Journal, Legal beat, July 11, pp. B1, 2.

Lambert, Thomas (1996). " Defusing the 'Population Bomb' with free markets." Policy Study 129. Center for Study of American Business, February. Washington University, St. Louis.

Iklé, Fred Charles (1994). Growth Without End, Amen? National Review March 7, pp. 36-44.

Leal, Donald R. (1998). Community-Run Fisheries: Avoiding the "Tragedy of the Commons." Population and Environment 19 (3), 225-246.

Levine, F.J. (1996). Science 271, March 22, 1649.

Lind, Michael (1995). America by Invitation. The New Yorker April 24, pp. 107-112.

Malthus, Thomas Robert (1789). An Essay on the Principle of Population. Edition (1976) with sources and criticism edited by Philip Adelman. W.W. Norton \& Co., New York.

Matloff, Norman (1998). Visa Program for High Tech Workers. Wall Street Journal, June 5, Letters.

National Research Council (1997). The New Americans. The National Academy of Sciences, Washington, D.C.

Pimentel, D., and Pimentel, M. (1991)." The Constraints Governing Ideal U.S. Population Size." Negative Population Growth, Teaneck, NJ.

Pimentel, David and Pimentel, Marcia (Eds.). (1996). Food, Energy and Society. University Press of Colorado, Niwot, CO.

Pimentel, David and Pimentel, Marcia (1997). Land, Energy, and Water. Revised edition. University of Colorado, Boulder.

Pimentel, David and Giampietro, Mario (1994). "Food, Land, Population and the U.S. Economy." Carrying Capacity Network, Washington, DC.

Pimentel, David, Harvey, C., Resosudarmo, P., Sinclair, K., Kurz, D., McNair, M., Crist, S., Shpritz, L., Fitton, L., Saffouri, R., and Blair, R. (1995). Environmental and economic costs of soil erosion and conservation benefits. Science 267, Feb. 24, 1117-1123.

Political Ecology Group (1998). "Wooing the Sierra Club: Hate Groups Make Unlikely Suitors." San Francisco, March 6, PEG, California.

Ruttan, Lore M. (1998). Closing the Commons: Cooperation for Gain or Restraint. Human Ecology 6,1, 43-66.

Simon, Julian. (1995). "The State of Humanity: Steadily Improving." Cato Policy Report 17 (5), Sept.Oct, 131.Cato Institute, Washington, D.C.

Stein, Robert (1995). Should We Still Welcome the Huddled Masses? Investors Business Daily September 11, p. B1. 
Tech Firms. (1996).USA Today, February 28, p. 1.

Trivers, R.L. (1971). The Evolution of Reciprocal Altruism. Quarterly Review of Biology, 46, 35-57.

Ventura, Stephanie, Martin, Joyce A., Mathews, T.J., Clarke, Sally C. (1996). "Advance Report of Final Natality Statistics, 1994." Supplement 44 (11), June, Tables 10 \& 11 (pp. 41-42). National Center for Health Statistics, Division of Vital Statistics, Bethesda, MD.

Williams, G.C. (1975). Sex and Evolution. Princeton: Princeton University Press.

Editorial responsibility: John Cairns Jr.,

Blacksburg, Virginia, USA
Williams, G.C. (1966.) Adaptation and Natural Selection: A Critique of Some Current Evolutionary Thought. Princeton, N.J: Princeton University Press.

Wilson, E.O. (1975). Sociobiology. Cambridge: Harvard University Press

Wolf, Charles Jr. (1994). The New Mercantilism. The Public Interest, 116, 96-106.

Youngquist, Walter (1997). GeoDestinies. Portland, OR: National Book Company

Manuscript (ms) accepted by editor: Jan 16, 2001

MS received at Headquarters: Jan 21, 2001

MS published on the web: Jan 23, 2001 